\title{
A Review of China-India Geopolitical Relations in the Context of Belt and Road Initiative (BRI)
}

\author{
Akkas Ahamed $^{1}$, Md. Sayedur Rahman ${ }^{2 *}$
}

${ }^{1}$ Associate Professor, Department of Political Science, University of Chittagong, Chittagong-4331, Bangladesh

${ }^{2}$ Assistant Professor, Department of Political Science, Faculty of Social Sciences, Begum Rokeya University, Rangpur -5400, Bangladesh \& Masters Student, Master's Programme in Socioeconomic and Political Development of Modern Asia, Faculty of World Economy and International Affairs, National Research University Higher School of Economics, Moscow, Russian Federation

DOI: $10.36348 /$ sjef.2020.v04i07.009

| Received: 19.07.2020 | Accepted: 28.07.2020 | Published: 30.07.2020

*Corresponding author: Md. Sayedur Rahman

\section{Abstract}

Both China and India are two neighboring nations sharing long borders. China is a North East Asian country, and India is a South Asian country bordering with Bangladesh, Pakistan, Nepal, Bhutan and Myanmar. China shares borders with South Asia, South East Asia, North East Asia, Central Asia, West Asia and Russian Federation. Geopolitically and geostrategically it is located in a center point. According to its size of population and by GDP purchasing power parity (PPP), it has been turned into as number one country in the World. China's economy is rapidly growing, and it will emerge as a global super power within very short time. However, India is a large country in the context of both geographical size and population. It is the second largest country in world taking into account of its size of population. It is a rising economy, and it has been turned into third largest economy by GDP purchasing power parity (PPP). In this study, some important geopolitical issues of Sino-Indian relations have been discussed in the context of BRI. Friendly relations between China and India are very crucial to ensure peace, security, stability, connectivity and, of course, economic development in the entire region. The main objective of this study is to provide some policy recommendations to improve the relations between China and India. The study is based on secondary data with some field level data which were collected through focus group discussions and observation.

Keywords: China, India, Geopolitical Relations, BRI, Border, Indian Ocean, South Asia, Connectivity, Trade, Cooperation.

Copyright @ 2020: This is an open-access article distributed under the terms of the Creative Commons Attribution license which permits unrestricted use, distribution, and reproduction in any medium for non-commercial use (NonCommercial, or CC-BY-NC) provided the original author and source are credited.

\section{INTRODUCTION}

China and India have been maintaining friendly relations since 1950s after India's Independence from British rule, and China's revolution in 1949. Both countries tried to continue warm relations between them. But due to undecided border claims by both countries their friendly relations have been put at severe risk in several times. Both countries have confronted several times along the border areas regarding border disputes. However, the world did not witness any major wars between these two nations except in 1962. Friendly relations between these two nations are immensely important for peace security, stability and economic development, through which the entire region can be benefitted economically.

Improvements of diplomatic and economic ties are vital in their bilateral relationship. their bilateral relationship. During the Second World War, where
British India was a major part, both China and India played a very important role in halting the progress of Imperial Japan [1, 2]. The relation between China and India has been characterized by border disputes, leading to three military conflicts, the Sino-Indian War in 1962, the incident of Chola in the year 1967 and another clash was, the Sino-Indian skirmish in 1987. Both countries conflicted at the Doklam hill in the undecided SinoBhutanese border in 2017 [3, 2]. However, both countries maintained friendly relations through establishing diplomatic and economic ties since 1980s. In the meantime, China has now become India's largest trading partner, and the two countries have similarly maintained warm relations in the strategic and military aspects $[4,2]$.

However, there was border conflict in 1967 between the two countries, at the end of the conflict, India declared it was able to establish a new "Line of Actual Control"; since then no further deadly incidents 
were occurred till 2020. However, two other conflicts were de-escalated in 1987 and 2013 respectively regarding the two different lines of actual control. Another conflict was de-escalated in 2017 at the Bhutanese controlled border area where both Chinese and Indian soldiers were put at severe danger. Multiple clashes broke out in June 2020 between China and India which resulted in deaths of twenty Indian troops. But the Chinese government denied that their troops had been died in the incident [5]. Although, the conflict did not further proceed, but peace is not existent along Sino-Indian borders. Undecided borders which are claimed by both sides are the core cause of conflicts between the two neighboring nations. It is supposed that the conflicts will arise again and again in future. But, people to people's contacts, trade and investment, connectivity, reducing trade imbalance, and transfer of technology and knowledge sharing can reduce the border tensions between China and India.

However, according to Karim Laskar, a scholar of Indian policy, "at present, both nations are cooperating on a variety of international issues [4]. Both countries' scholars always emphasize on the importance of mutual cooperation regarding trade and investment to avoid geopolitical conflicts in the region.

However, as part of improving the relationship between these two nations, several agreements, memorandum of understandings have been signed. For example, India through Bangladesh-China-IndiaMyanmar corridor (BCIM) wants to connect its northeast region with Southeast Asia, but China wants to intermingle BCIM with BRI, where India is skeptical about the intention of China. India thus feels that already the progress of BCIM is lukewarm and merger would further slowdown the progress. The Maritime Silk Road is trying to ensure China's naval presence in the Indian Ocean region, which is already being carried out by dint of the so-called 'string of pearls strategy'. China argues that more than 70 per cent of their oil imports supply is done via this ocean, therefore its purposes are for refueling, commercial purposes and ensuring sea lane security in the Indian ocean, it has no plan to contain India, and it also argues that through the BRI and BCIM, the entire region of South Asia will be benefitted economically and geopolitically. However, India is not agreed by these arguments as it threatens India's future naval power projects and its influence in the region [6]. Apart from China-Pakistan Economic Corridor (CPEC) issue, the Indian government (Ministry of External Affairs in May 2017) from time to time has expressed serious concerns about the effect of Belt and Road Initiative (BRI) that it may cause in unsustainable debt burdens for many South Asian countries.

Many countries that have received Chinese loans are now in serious debt crisis and those countries are frustrated as to how they would pay back the money to China, also these loans created an instability and disorder in the region, here we can give an example of Sri Lanka [6]. As a result, in December 2017, the Hambantota port was handed to China for a period of 99 years lease while China holds 70 per cent stake in this strategic port. Thus, this remains the best example of unsustainable loans, which ultimately are allowing China to gain significant economic and strategic advantages in the Indian Ocean region. Furthermore, some of the news reports and studies have shown that, through BRI there is a possible risk of Chinese companies that they might be interested in grabbing host countries resources with unsustainable loan practices leading to high levels of debt and weakening the economy of the recipient state. But, the China's perception regarding the BRI is quite optimistic that it is committed to ensure equal opportunities for all stakeholders including India. Similarly India has a huge potential to be a global power considering its territorial size, economy and population. In terms of military power, both China and India have huge military forces and substantial equipment with nuclear weapons. Thus both countries should cooperate in any development project in the region instead of doing parochial politics.

This review paper has discussed about the various geopolitical issues between China and India, and at the end of the study there has been provided with some policy recommendations for both countries. After all, peace, security, stability and development are more important than parochial politics. Both the nations should come ahead to the path of peace, justice and development with win-win situation for the greater interest of the region. The people of China and India are truly peace loving, thus the process of peace should be followed in the region, including China and South East Asia. Both countries should come ahead to ensure peace and security in the entire region. This study has emphasized on the importance of friendly relations between China and India which are essential for sustainable development.

\section{METHODOLOGY OF THE RESEARCH}

This research work has been carried out using qualitative research method. The qualitative data have been collected by using an unstructured questionnaire, and the study has collected required data from the key informants on Sino-India Relations. It has mixed both primary and secondary sources of data. The authors have collected field level data on the topic, and one of the authors of this paper has paid visit to China and India to collect relevant data on Sino-Indian geopolitical relations. Secondary sources of data like books, journals, magazines, archival materials, official documents, letters, and materials have been used to make in-depth analysis, interpretation, and reinterpretation for this study. This study is based on an interpretative and analytical method to carry out the important study on geopolitical relations between China and India in the context of BRI. The qualitative method 
is considered the most appropriate one for this study. Moreover, this study is descriptive and explanatory in nature with some historical analysis of geopolitical and geostrategic relations between China and India.

\section{IMPLICATION OF BELT AND ROAD INITIATIVE (BRI)}

However, it has been proven by different write-ups and research that creation of China-led economic area is very crucial for China. There are quite a lot of purposes of the BRI comprising development of new trade markets, enhancement of external investment, removal of overloading, revival of provincial economic development, internationalization of the China's currency, RMB, improving neighborhood relations, etc. Through the divergence of foreign trade and the rise in external investment, it is supposed that China, being the world's second-largest economic power is keenly interested in acquiring its own economic and political interests, and is committed to create a new atmosphere in which China can easily involve in various infrastructural development and economic activities [7]. On the origin of the BRI, there is needed a goal of founding an economic area where China can lead and compete effectively with other economic powers of the world. BRI is an essential element for developing an economic area to promote local infrastructure and linkages. There have been taken many initiatives as part of the development of BRI, for example, Railways, Roads, and ports. Of them, the Sino-European shortest rail cargo transport system has drawn a global attention. In the meantime of its opening in 2011, around 5000 deliveries have already been operated by September 2017, and 33 towns in China and 33 towns in 12 different countries of Europe which are jointly linked. A lot of cargoes were presently occupied by IT produces which are made in China for example mobile phones and private computers, but the exports products are varying including clothes products, motor vehicles and their parts, foodstuff, timber and furniture, and machines and equipment. Through the project of BRI, the Chinese firms are being greatly benefitted through construction and infrastructure development. It is also true that, the BRI has provided huge opportunities in the construction, engineering, and infrastructure-oriented industrial development [7]. There are huge demands for taking steps for intraregional structure and network which can attract global attention.

These are the BRI's basic principles: showing respects for sovereignty to other nations, mutual inviolability through BRI, non-interference to internal affairs of other countries, peaceful coexistence with neighboring nations and other distant neighbors, equality and justice irrespective of their affiliations with other local and international organizations, reciprocity among the different stakeholders, open framework for all member countries, socio-economic and political cooperation among the partner states, ensuring effective and sustainable market mechanism for all partners, and finally win-win situation will be ensured and very warm relationship among participant countries will be encouraged to implement BRI effectively and successfully [7]. BRIs target areas are: it has a plan to link East Asian and European countries and relevant economic zones, infrastructure such as transportation system, communication, energy, and development; cooperation in the trade and investment such as facilitation of cooperation, lifting of various kinds of barriers, investing in the business climate development, and FTA; increasing money exchange, promoting Asian bond market, Asian Infrastructure Investment Bank (AIIB), New Development of (BRICS) Bank, and Silk Road Fund; and an agreement on mutual cooperation framework for all stakeholders, Asia-Pacific Economic Cooperation (APEC), Shanghai Cooperation Organization (SCO), ASEAN plus one China, Central Asia Regional Economic Cooperation (CAREC), Asia Europe Meeting (ASEM), and Greater Mekong Subregion (GMS) Economic Cooperation [7]. In a nutshell it can be said that the BRI project will, of course involve all Asian and European countries through roads, highways, infrastructure, trade and investment, and people to people's contacts for geopolitical interactions and economic relations.

Here it should be mentioned that the BRI is very crucial in the context of China's trade and investment, and its huge exports. China undoubtedly would be greatly benefitted through BRI, because it is the largest exporting nation in the world. Whole Asian and European countries will come under the business interests of China. Moreover, China will have a great chance to influence in the internal affairs of almost all countries of Asia and Europe. But, there is a doubt that small nations will be trapped with debt crisis; and some Asian, African and European countries have already been put at risk in relation to debt trap of China. However, it should me mentioned here that, all stakeholders should be careful in dealing with the BRI of China, particularly while dealing with loans and other debts. On the other hand, there is a great opportunity to develop the low income countries through the various infrastructure development programs of BRI.

\section{INDIA'S PERSPECTIVE ON BELT AND ROAD INITIATIVE}

Some experts and academicians in India have argued that there are vast opportunities for India to be benefitted through BRI project, for example: India will easily have an access to new economic markets, resources and commodities from Central Asia and the Middle East will come into India through the roads and highways built on BRI financing. In the last few decades, India was trying to connect with South Asia, South East Asia, Central Asia and West Asia. Through the implantation of BRI, India's long cherished dream of regional connectivity will come into effect. Accordingly, the BRI offers an excellent prospect to 
realize these aims: the BRI is not merely concerned with road and rail connectivity, as it too comprises regional connectivity and construction of digital and Internet infrastructure. We know that India is a skilled country in information and communication technology industry, therefore the BRI will be helpful to expand India's ITC industry. Equally, BRI will be nationally very advantageous, because India's mission to become the industrial center of Asia can be truly understood, regarding the "Make in India" campaign, and it will help create new job prospects. Besides, it will provide jobs opportunities to not only government sectors but also to the private sectors to a large extent. All of the South Asian countries have become the members of BRI officially except the Kingdom of Bhutan [8, 9]. If it is considered from the aspects of infrastructure development, regional connectivity, people to people's contacts, trade and investment and geopolitical importance, the BRI is undoubtedly a great initiative for the entire region.

Days before the 2017 BRI Forum's meeting took place, China signed up fresh agreements with Nepal, Sri Lanka, Afghanistan, Pakistan, Bangladesh, and Myanmar. In addition, the head of states of these countries in their respective speech at the forum went on to congratulate President Xi Jinping for his regional leadership and welcomed Chinese investments in their respective country. This clearly underlines that these countries are supporting the BRI. But India has totally failed to provide any such kind of development project in the region for economic growth and prosperity. Apart from South Asian nations, the Southeast Asia countries and Central Asia countries have shown their keen interest for becoming the integral part of BRI [10,9]. In addition, despite the US, EU and Japan expressing their worries on BRI that it might not follow transparency, responsibility, accountability, public procurement, environmental ethics, mutuality in trade and investment and other issues, they did not hesitate to send their representatives to the BRI Summit (May 2017). Despite huge potential of BRI, India is suspicious about its goals and objectives that it can be used for geopolitical influence in South Asia, South East Asia, Central Asia and West Asia including India. That's why India did not send any representative to the forum of BRI. There are some dissenting views among Indian government officials and scholars on BRI. Some think that BRI is good for India's economic prospects, but on security and geopolitical grounds, BRI will not be good for India. But, the reality is that either India supports BRI or not, it will continue to proceed to reach its goals at national, regional, and global level. Many Indian academicians think that India should join BRI considering its economic interests and regional markets.

\section{INDIA'S INFLUENCE IN SOUTH ASIA IN THE CONTEXT OF CHINA-INDIA RELATIONS}

Generally, India has always considered the South Asian Region as its natural sphere of influence.
However, in recent decades the region has witnessed China's increasing political, economic, and cultural influence and presence in South Asian countries including India. This has been intensified particularly in Nepal, Bangladesh, Sri Lanka and Maldives. For example, China has already invested US\$14 billion in infrastructure in Sri Lanka since 2005, it has pledged US $\$ 38$ billion to Bangladesh and planned to invest and provide US\$8 billion credit for Nepal [11, 9]. Moreover, Pakistan's Prime Minister Imran Khan is taking Pak-Sino relations to the next level following his visit to China (in September 2018). And he is trying to inspire Saudi Arabia in joining the CPEC as the third "strategic partner". These developments constitute a major concern for India due to China's greater geopolitical influence. With the BRI initiative, India's fear is growing day by day, apart from Bhutan, all the other neighbors are now officially part of BRI. The three corridors: BCIM, CPEC, the MSR and the TransHimalayan Economic Corridor linking to South and Southeast Asian regions and the infrastructure projects which are directly connected with those have a direct impact on India's geopolitical and geostrategic interests $[12,9]$. For instance, these projects will go into India's continental and maritime borders and are affecting its security interests and strategic environment. It also alters the existing power dynamics in the region.

Although, India does not discourage the infrastructure development in the region, but it is very much worried regarding the some geostrategic issues of certain Chinese initiated activities in the region through BRI. India also thinks that that Beijing may, perhaps, ensure its commercial presence in the Indian Ocean to gain its geopolitical, military and strategic interests. For example, the advantageously situated port of Hambantota has been leased to China forcefully in December 2017. The port was built on Chinese loans and labor with high interest rates. Sri Lanka was not able to repay the loan and incurred a debt burden. Therefore, India considers the China's economic projects as a tool for their foreign policy and hegemonic security policy $[6,9]$. Pakistan's has always been proactive to China and now has provided its supports to BRI which is not surprising, but in recent times, there are many concerns that, "Pakistan is striving to allow China to build some economic and trade establishments, and a strategic military base in Pakistan's territory".

According to the report of Pentagon, "China is keenly interested in building military bases in the friendly countries and in the areas which are geopolitically important to ensure its military influence and economic interests, such as Pakistan and other friendly countries $[13,9]$. In this context, India is very much worried that it directly impacts its security interests. If China emerges as Pakistan's sole trade window to the world, this will have repercussions for India. In addition, the BRI intends to connect the South Asian region through joint projects, but according to 
many observers, it does not properly evaluate the active role of the South Asian Association for Regional Cooperation (SAARC), and the role of India as a regional power and strong neighbor. India thinks that the BRI will not bring about any success to India; rather it will pose a threat to India both geopolitically and militarily instead of economic opportunities.

\section{CHINA-INDIA GEOPOLITICAL RELATIONS IN THE CONTEXT OF BORDER CONFLICTS}

Sino-Indian border dispute is an ongoing territorial dispute over the sovereignty of some territories between China and India. For example, Aksai Chin, which is located in the Indian region of Ladakh, or the Chinese self-ruling regions of Xinjiang and Tibet; this area is a nearly unpopulated high-altitude desert. The other undecided area located in the south of the McMahon Line, previously identified as the North East Frontier Agency and now called Arunachal Pradesh. McMahon Line was a part of the 1914 Simla agreement between British India and Tibet, where China was not a part of that agreement [14].

As of 2020, India has continued to explain that the McMahon Line as the lawful border between the two countries, but China has never acknowledged that border demarcation, and they say that Tibet was never an independent country, it was part of China. In 1962, Chinese soldiers crossed into the McMahon line, and they were able to advance to establish a "Line of Actual Control" in a one month of war between the twocountries. The 1962 Sino-Indian War was fought in the disputed area. There was an agreement to put an end to the dispute in 1996 where both countries included the term of "confidence-building measures" and they jointly agreed regarding the Line of Actual Control. But, in 2006, the China's ambassador to India clearly claimed that all parts of Arunachal Pradesh are Chinese territory amidst a military buildup [15]. And both countries demanded travels and activities at the northern slope of Sikkim [16]. In 2009, India declared that it would take step to deploy supplementary military forces along the border [17]. In 2014, India offered a proposal to China that it should acknowledge the policy of "One India" to resolve the existing border disputes amicably between the two nations.

There was a battle between China and India along Sino-Bhutanese border, Duklam, in 2017. The world again has also witnessed a fatal clash in Ladakh in June 2020 where twenty Indian soldiers were reportedly died. As we have mentioned, there were huge battles along India-China borders, and the conflicts will continue to prevail in future to come since border security and establishment of territorial claims are so crucial for both countries. The world has seen several battles between China and India in last few decades along the border areas. It is very frustrating for the entire region that unless border disputes are resolved amicably, the peace, security, stability and development are not possible. Both countries need to show respects to the peaceful co-existence and regional stability.

\section{SINO-INDIAN GEOPOLITICAL AND GEOSTRATEGIC CONFLICT IN THE INDIAN OCEAN}

The Indian Ocean which is widening from the Persian Gulf and the coast of East Africa to the Malay Archipelago and the shores of Australia together with all its tributary water bodies (Persian Gulf, Red Sea, Malacca Strait, and so on), each of its coastal position, as well as the land-locked states for which the transit to and from the sea is mostly preoccupied with towards the Indian Ocean constitutes the Indian Ocean Region (IOR) $[18,19]$. It is a strategically significant region which was emphasized by a quote ascribed to an American naval officer and strategist Alfred Thayer Mahan stating that "Whoever controls the Indian Ocean dominates Asia. This Ocean is connected to the seven oceans in the twenty-first century; the future commercial activities of the whole world will be decided in these seawaters" [19].

The region is rich in natural resources, containing $62 \%$ of the world's proven oil reserves, $35 \%$ of its natural gas, $40 \%$ of its gold, $60 \%$ of its uranium, and $80 \%$ of its diamonds. Moreover, it is vital to global energy flows and therefore has a major position in the supply side of global energy security [20, 19].

It is used as a vital transit route for oil supply from the Persian Gulf to the countries of Asia and Europe. 17 million barrels of oil a day, constituting $20 \%$ of the world's oil supply and $93 \%$ of oil exported from the Gulf, transits by tanker through the Strait of Hormuz and into the western reaches of the Indian Ocean $[21,19]$.

Although a large portion of oil is transported to Europe and the Americas via the Suez Canal and the Cape of Good Hope, the route towards Asia is more important, as Arab countries' oil meets approximately $75 \%$ of Asian nations' imports need. Due to this importance, the route is identified as the "new silk road" [21, 19]. The region with such rich energy resources and strong trade volume is essential for Asia's two rising powers, China and India, which are increasingly reliant on oil transiting through the region. While more than $80 \%$ of China's imported oil and natural gas is carried through the Indian Ocean and the South China Sea $[22,19]$.

Almost $80 \%$ of India's crude oil is imported by sea, where the Indian Ocean is used [23]. Therefore, the security of Indian Ocean and sovereignty over it is so crucial for India that without a full control of the Ocean it is impossible to safeguard Indian interests of trade and geopolitical influence in the entire region. Particularly, the energy security of India cannot be attained without the security of Indian Ocean. 
Since both actors take into account the control of this vital seaborne energy trade route by a foreign and potentially hostile power as a threat to their national interests, they desire to enhance their geostrategic power and do not expect any contestants in the region which may put barriers to their geopolitical influence. Both India and China race for strong influence in the Indian Ocean regime which has caused in a deliberate rivalry between them which makes the entire Indian Ocean a disputed hotspot. While China does not officially accept the existence of such a strategic competition and identifies India as a strategic partner in regional and international affairs, India on the other hand, according to its official statement, recognized China as a challenging country in the context of commerce and trade, although rising strong economic collaboration between the two countries. Though both players do not overtly acknowledge the existence of such a strategic competition in the IOR, their initiatives in the region have already demonstrated the clues of a covert strategic rivalry between China and India. China has deployed soldiers in the Indian Ocean through which it has ensured its naval presence in the region, and China has established strong economic, geopolitical and military ties with Myanmar, Sri Lanka, and Pakistan including Bangladesh, through the construction and improvement of port facilities, rail links, gas pipelines and Signal Intelligence Facilities etc., which would help to boost its regional influence in the Indian Ocean [19].

On the other hand, India, which has a more advantageous position when compared to China, aspires to maintain its pre-eminence and it wants to prevent China from challenging its predominant status in the region. India, which perceives the Chinese strategic penetration into the Indian Ocean littorals and its naval activities in the region as a profound strategic challenge to its vital political, economic and strategic interests and its predominant position in the region, therefore India has adopted a balancing policy with China [19]. India launched counter initiatives including establishing, broadening and deepening its cooperation and partnership with the USA, Iran, Myanmar and Sri Lanka to contain the growing Chinese influence in the region.

China has built a $700 \mathrm{~km}$ rail link between Lhasa, Tibet with Khasa, Nepal for accelerating the Sino-Nepali economic integration by improving the transport infrastructure in the Himalayan region and reducing Nepal's dependence on India. Another Chinese initiative in Nepal is the railway project that will link Golmud in the Qinghai province to Lhasa in Tibet, which is designed to integrate Tibet with the Chinese economy $[16,19]$.

On 12 May 2017, Nepal and China signed a 'Memorandum of Understanding on the Belt and Road
Initiative' in Kathmandu, which makes China and Nepal partners in the BRI. Myanmar is another strategically salient country for China and the BRI, which can provide China with an overland transportation link to the Indian Ocean. Due to its geographical proximity to the Strait of Malacca, Myanmar enables China to export its goods directly through its own territory. China and Myanmar have a close economic, political and arms supply relationship [24]. China and Myanmar have an increasing military cooperation since 1988 [25]. During the 1990s, China was involved in the development or upgrading of several ports in Myanmar and the construction of a SIGINT facility in the Bay of Bengal. China has already started to construct highways and rail networks connecting Yunnan of South China and several ports in the Myanmar's costal area which are linked to the Bay of Bengal. In 1992, Beijing pledged that China would provide great assistance for the modernization of the marine facilities in Myanmar, including the Hianggyi Island and the Coco Islands [24, 19].

The Coco Islands which are controlled by Myanmar have a very geostrategic situation for the naval force of China. They are only about $30 \mathrm{~km}$ north of the Indian-controlled Andaman Islands. By the year 2050, China, which is planning to achieve world-class blue water naval status, is expecting that Myanmarcontrolled islands will provide China with a direct access to the Pacific and the Indian Oceans. By not passing through the Strait of Malacca to reach the Bay of Bengal, the Chinese Navy would shorten the distance by $3000 \mathrm{~km}$, reducing the journey by five to six days $[26,19]$. China has developed a current investigation and microelectronic intelligence scheme on the Coco Islands in 2003 to monitor India's military movements, including missile testing in the Indian Ocean [25]. The discovery of oil and gas fields in Myanmar is another factor that increases its significance for China. Production sharing agreements were signed between the Chinese National Offshore Oil Company and the Myanmar Oil and Gas Enterprise between October 2004 and January 2005 [27, 19]. In order to mitigate its strategic vulnerability due to its high degree of dependence on the Strait of Malacca for the importing of hydrocarbons from the Middle East [28], the socalled Malacca Dilemma, it has invested heavily in Myanmar's oil and natural gas pipelines for the purpose of forming an alternative energy transit route.

The oil and gas pipelines between the new deep-water port of Kyaukpyu in Myanmar and China's southern Yunnan province for transporting gas from Myanmar's offshore gas fields, and oil which is shipped from the Middle East have a significant role for China $[24,19]$. And the construction of a railway between Kunming and Lashio are other Chinese attempts in Myanmar to enhance bilateral economic relations [26]. This pipeline will play a very significant role to decrease the sea-route distance in 1820 nautical miles 
which is account for $10 \%$ of China's total oil flow through the Strait of Malacca [29, 19].

Pakistan is another strategically salient country, which can provide China with an alternative overland transportation link to the Indian Ocean, like Myanmar. Pakistan has been seen as an all-weather strategic cooperative partner by China [30, 19]. China considers Pakistan an important bypass line which enables it to access to the Indian Ocean directly, instead of using long seaborne trade routes stretching from its own coast to the Middle East [29]. Taking into account of China's trade expansion, it has built some infrastructure projects in Pakistan to promote the Chinese exports products to the different countries in the world.

A large part of China's trade is carried out through a very long distance passing through the Strait of Hormuz-Indian Ocean-South China Sea transportation line which results in a great loss of time and has serious security risks. For this reason, China aims to reach the Arabian Sea by passing through Kashmir and Pakistan from its mainland instead of using this long and time-consuming South China Sea route through the Malacca straits.

\section{IMPROVING BILATERAL RELATIONS BETWEEN CHINA AND INDIA}

Despite the perpetuating security and border irritants in Indo-Sino relations, Prime Minister Narendra Modi and President Xi Jinping have met regularly like their informal summit in Wuhan (April 2018), during the SCO meeting in Qingdao (June 2018), at the BRICS summit (July 2018), and G-20 Summit (November 2018). Subsequently, economic ties are increasing. This was well reflected in a meeting (June 2018) between Jinping and Modi, where they agreed to enhance bilateral trade to US $\$ 100$ billion by 2020 (the present trade is US\$84 billion), and China agreeing to import non-Basmati rice and sugar from India. In return, India will allow China's state-owned Bank of China to open its branch in Mumbai [31, 9]. Moreover, there is an ongoing trade war between the US and China as the US carries out its threat to impose tariffs on all US $\$ 507$ billion worth of Chinese exports to the US. If this happens, then the Chinese economy will be severely jeopardized with long-term annual GDP growth estimated to fall below 4.5 per cent [32]. In this circumstance, China will have to depend upon India to keep its trade and economy running. Over the decades, conflict and cooperation have become important elements in India-China relations.

The two countries have cooperated on strengthening bilateral political and economic ties. They have increased cooperation on transnational issues like terrorism (minus Pakistan-sponsored terrorism), global warming, economic crisis, piracy, drug trafficking, Islamist fundamentalism and other security issues. Both share common interests in maintaining regional stability like promoting economic growth and achieving energy security in the region $[33,9]$.

Both opposed the US use of military around the world, clearly indicating that they both want a multi-polar world. The relations were further enhanced with the signing of the China-India strategic and cooperative partnership for peace and prosperity in 2015. At the same time, China is also India's largest bilateral trading partner. Both countries are also the powerful members of the BRICS group (Brazil, Russia, India, China, and South Africa) and the SCO, among others. Both the countries take the same initiatives regarding the industrialized nations in international trade and investment and climate change conferences. However, there are many irritants which have the potential of snowballing into a major conflict like territorial and border disputes, river water disputes, Tibet issue, China's overwhelming economic, military, nuclear and political support to Pakistan, China's growing influence in South Asia and South East Asia, China's attempt to deny India a major role in AsiaPacific region and counter India's legitimate aspirations as a major maritime power in the Indian Ocean, and opposing India's strategic interests in the South China Sea [9]. Furthermore, China continues to prevent India's entry into the NSG and UNSC and other economic, political and security forums and groupings. Hence, India-China relations have been a policy of containment, confrontation and cooperation, which will continue and is the same case in the Asia-Pacific. In this context, both the countries can explore the possibilities of working over a win-win situation with regard to BRI.

\section{CONCLUSION}

Both China and India are two rapidly growing economies with substantial geopolitical implication in the World. The Region has covered a large area of the world map with huge population and natural resources. The relationship between the two nations are very crucial for ensuring peace, security, stability, people to people's contacts and, of course, economic development in the region. But countries are confronting each other in the border areas, huge trade imbalance between the two countries, and a huge gap in human resource development. China has gained rapid progress in industrial development, where India is lagging behind which needs to be resolved as soon as possible. Geographically China is several times bigger than India, and the country of India has many socioeconomic, political and ethnic problems. China has also some ethnic issues. But it has minimized the gap through different economic and social development programs at the provincial level. Ethnic, political, social, cultural, economic and regional disparities are enormous in India.

Besides, the country has been influencing both Bangladesh and Nepal on geopolitical, economic and 
strategic matters. It has several times put pressures on Bangladesh and Nepal to refrain them from China's investment and infrastructural development. South Asian small countries need foreign direct investments in the various development projects including the building ports, highways and power plants. India is a poor country with huge corruption, and lack of proper policy as to how industrialize like China. But it has put barriers to many South Asian countries through its foreign policy, security, military and political threats in the context of economic development and foreign policy. China has very potential to come up with huge trade and investment in the region. China should not be considered as threat, rather it can be considered as an opportunity for the South Asian countries including India. South Asian countries should realize the economic capacity of China. Europe and America's economies are not so well at this time where China has strong economic foundation with US \$ 30 trillion by GDP purchasing power parity (PPP). And this amount is the largest in the World by GDP (PPP). But in terms of nominal GDP, USA has still remained as number one economy of the World. After few years, China will, of course, overtake US economy in both aspects of GDPs. India along with the entire world has to understand this reality. Thus, we think that India should not fight with China, rather it should come ahead to cooperate with China in trade and investment, regional connectivity and economic development including Belt and Road Initiative (BRI). India cannot sustain in fight against China in terms of any issue. Thus both India and China should cooperate in geopolitical and strategic issues to resolve the remaining problems amicably instead of confronting each other.

\section{ACKNOWLEDGEMENT}

We hereby acknowledge the input of every member of this team for their tireless efforts during this work.

\section{REFERENCES}

1. Williams, B. (2004). World War II. Twenty-First Century Books. ISBN: 978-0-8225-0138-1. Zhu, Z. (2011). China-India Relations in the 21 st Century: A Critical Inquiry. Indian Journal of Asian Affairs, 24(1/2), 1-16.

2. Rahman, M. S. (2020). China's Foreign Policy Trends towards India, Late 20th-Early 21st Century (Economic Aspect) European Modern Studies Journal 4(2).

3. Joshi, M. (2017). Doklam, Gipmochi, Gyemochen: It's Hard Making Cartographic Sense of a Geopolitical Quagmire Archived at the Way back Machine

4. Lancaster, J. (2005). India, China Hoping to 'Reshape the World Order'Together. Washington Post, 12.

5. Goldman, R. (2017). "India-China Border Dispute: A Conflict Explained". The New York Times. Retrieved 27 June 2020.
6. Darshana, B. M. (2018). "India's Answer to the Belt and Road: A Road Map

For South Asia"

7. Ohashi, H. (2018). The Belt and Road Initiative (BRI) in the context of China's opening-up policy. Journal of Contemporary East Asia Studies, 7(2), 85-103.

8. Das, K. C. (2017). The making of one belt, one road and dilemmas in South Asia. China Report, 53(2), 125-142.

9. Kumar, S. Y. S. (2019). China's Belt and Road Initiative (BRI): India's Concerns, Responses and Strategies. International Journal of China Studies, 10(1), 27-45.

10. Kohli, H. (2017). Looking at China's Belt and Road Initiative from the Central Asian Perspective. Global Journal of Emerging Market Economies, 9(1-3), 3-11.

11. Wagner, C., \& Tripathi, S. (2018). "India's Response to the Chinese Belt and Road Initiative", SWP Comment No. 7, 1-4. Berlin: Stiftung Wissenschaft und Politik

12. Chien-Peng, C. (2018). "What are the Strategic and Economic Implications for South Asia of China's Maritime Silk Road Initiative?", The Pacific Review, 31(3), 315-332. https://doi.org/10.1080/09512748.2017.1375000

13. Kaura, V. (2017). "Understanding India's Response to China's Belt and Road", Asian Times.

14. Hoffmann. (1990). India and the China Crisis, 19.

15. Bhaumik, S. (2010). "India to deploy 36,000 extra troops on Chinese border", BBC, Archived 2 January 2012 at the Way back Machine

16. Ramachandran, S. (2008). Nepal to get China Rail Link. Asia Times Online. Retrieved December 4, 2016, from http://www.atimes.com/ atimes /So uth _Asia/JE15Df01.html

17. Wall Street Journal. (2009).

18. Bouchard, C., \& Crumplin, W. (2010). Neglected No Longer: The Indian Ocean at the Forefront of World Geopolitics and Global Geostrategy. Journal of the Indian Ocean Region, 6(1), 26-51

19. Kaya, T. O., \& Kilic, F. (2017). Sino-Indian Strategic Rivalry in the Indian Ocean Region the journal of humanity and society.

20. Cordner, L. (2010). Rethinking Maritime Security in the Indian Ocean Region. Journal of the Indian Ocean Region, 6(1), 67-85.

21. Erickson, A. S., Walter III, L. C., \& Mikolay, J. D. (2010). Diego Garcia and the United States' Emerging Indian Ocean Strategy. Asian Security, 6(3), 214-237.

22. Weimar, N.D. (2013). Sino-Indian Power Preponderance in Maritime Asia: a (re-)source of Conflict in the Indian Ocean and South China Sea. Global Change, Peace \& Security, 25(1), 5-26.

23. Indian Navy (IN). (2015). Ensuring Secure Seas: Indian Maritime Security Strategy. Naval Strategic Publication. Retrieved June 22, 2017, from https://www.indiannavy.nic.in/sites/default/files/In 
dian_Maritime_Security_Strategy_Document_25Ja n16.pdf

24. Brewster, D. (2015a). An Indian Ocean Dilemma: Sino-Indian Rivalry and China's Strategic Vulnerability in the Indian Ocean. Journal of the Indian Ocean Region, 11(1), 48-59.

25. Geng, L. (2007). Sino-Myanmar Relations: Analysis and Prospects. Culture Mandala: The Bulletin of the Centre for East-West Cultural and Economic Studies, 7(2), 1-15.

26. Shee, P. K. (2002). The Political Economy of China-Myanmar Relations: Strategic and Economic Dimensions. Ritsumeikan Annual Review of International Studies, 1, 33-53.

27. Van Gelder, J.W., \& Law, H. (2009). Financing of Oil Companies in Burma. A research paper prepared for Arakan Oil Watch. Retrieved January 11, 2017, from https://www.banktrack.org/download/financing_of _oil_companies_in_burma.

28. Kaplan, R.D. (2013). China's String of Pearls?. Stratfor. Retrieved June 30, 2017, from https://worldview.stratfor.com/weekly/chinas-

string-pearls

29. Khurana, G.S. (2008). China's 'String of Pearls' in the Indian Ocean and its Security Implications. Strategic Analysis, 32(1), 1-39.

30. Weidong, S. (2016). Remarks by Chinese Ambassador Sun Weidong at the Reception Celebrating the 67th Anniversary of the Founding of the People's Republic of China. Retrieved October 07, 2017, from http:// www.fmprc.gov.cn/mfa_eng/wjb_663304/zwjg_66 5342/zwbd_665378/t1402338.shtml.

31. Sengupta, R. (2018). "Modi Rules out Joining China's Mega Belt and Road Initiative", The New Indian Express, 10 June, available at newindianexpress.com/nation/2018/jun/10/modirules-out-joining-chinas-megabelt-and-roadinitiative-1826226.html

32. Merchant, M. (2018). "The Cure for India-China Relations",

33. Panda, J. (2016). India-China Relations: Politics of Resources, Identity and Authority in a Multi-polar World Order, New Delhi: Routledge. 